\title{
Feeding habits and habitat of herbivorous mammals from the Early-Late Hemphillian (Miocene) of Costa Rica
}

Víctor Adrián Pérez-Crespo, César A. Laurito, Joaquín Arroyo-Cabrales, Ana L. Valerio, Pedro Morales-Puente, Edith Cienfuegos-Alvarado, and Francisco J. Otero Acta Palaeontologica Polonica 63 (4), 2018: 645-652 doi:https://doi.org/10.4202/app.00517.2018

Carbon and oxygen stable isotope values in the dental enamel of fossils were used to infer the diet and habitat of the extinct equids Calippus hondurensis, Dinohippus mexicanus, and Protohippus gidleyi, the gomphothere Gomphotherium hondurensis, and the llama Hemiauchenia vera of the Early-Late Hemphillian (Hh2) from San Gerardo de Limoncito, Puntarenas province, Costa Rica. The results suggest that these mammals fed mainly on $\mathrm{C} 3$ plants and lived in clearings of rainforests. This contrasts with previous studies from North America that indicated that the same species lived in forest savannas and fed mainly on $\mathrm{C} 4$ plants, but it is similar to the results obtained from the palynological record of the area, as well as with several vegetation models suggesting the presence of humid tropical forest during the Miocene in Central America.

Key words: Mammalia, carbon and oxygen stable isotopes, Neogene, Hemphillian, Costa Rica.

Víctor Adrián Pérez-Crespo [vapc79@gmail.com], Instituto de Geología, Universidad Nacional Autónoma de México, Circuito de la Investigación Científica S/N, Ciudad Universitaria, Del. Coyoacán, 04150, México. César A. Laurito [clauritomora@ina.ac.cr], Instituto Nacional de Aprendizaje, La Uruca, San José, Costa Rica; Departamento de Historia Natural, Museo Nacional de Costa Rica, 749-1000, San José, Costa Rica. Joaquín Arroyo-Cabrales [arromatu@ hotmail.com ], Laboratorio de Arqueozoología “M. en C. Ticul Álvarez Solórzano”, Subdirección de Laboratorios y Apoyo Académico, INAH, Moneda 16 Col. Centro, 06060, México. Ana L. Valerio [avalerio@museocostarica.go.cr], Departamento de Historia Natural, Museo Nacional de Costa Rica, 749-1000, San José, Costa Rica. Pedro Morales-Puente [mopuente@unam.mx], Edith Cienfuegos-Alvarado [edithca@unam.mx], and Francisco J. Otero [fotero@geologia.unam.mx], Instituto de Geología, Universidad Nacional Autónoma de México, Circuito de la Investigación Científica S/N, Ciudad Universitaria, Del. Coyoacán, 04150, México; Laboratorio de Isótopos Estables, Laboratorio Nacional de Geoquímica y Mineralogía, LANGEM-UNAM, Ciudad Universitaria, Coyoacán, 04150, México. 
This is an open-access article distributed under the terms of the Creative Commons

Attribution License (for details please see creativecommons.org), which permits unrestricted use, distribution, and reproduction in any medium, provided the original author and source are credited.

Forill text $(249.5 \mathrm{kB})$ 